\title{
Recenzja
}

\section{Kodeks wyborczy. Wstępna ocena, pod red. Krzysztofa Skotnickiego, Wydawnictwo Sejmowe, Warszawa 2011, ss. 296}

Kodeks wyborczy. Wstępna ocena to zbiór dziesięciu opracowań przygotowanych przez specjalistów w dziedzinie prawa wyborczego, reprezentujących różne ośrodki akademickie. We Wstępie K. Skotnicki zwraca uwagę na problemy, które towarzyszyły pracom nad wydaniem tej książki. Kodeks wyborczy ${ }^{1}$ w okresie vacatio legis był bowiem kilkakrotnie nowelizowany, a niepewność co do jego wejścia w życie wywoływało oczekiwanie na wyrok Trybunału w przedmiocie jego zgodności z Konstytucją. Mimo tych trudności recenzowana publikacja, będąca próbą wstępnej oceny ustawy uchwalonej zaledwie pół roku wcześniej, została wydana przed wyborami parlamentarnymi w 2011 r. i uwzględnia dokonane na ten moment zmiany Kodeksu wyborczego oraz główne tezy wyroku Trybunału Konstytucyjnego z 20 lipca 2011 r., sygn. K 9/112.

Tom otwiera opracowanie autorstwa K. Skotnickiego, opisujące przebieg prac nad Kodeksem wyborczym. Autor nie tylko przedstawia poszczególne etapy procedury ustawodawczej, ale również analizuje tempo prac nad ustawą oraz aktywność osób zaangażowanych w jej przygotowanie. Opisując przebieg prac merytorycznych, zwraca uwagę na zagadnienia sporne, które wywołały największą dyskusję w trakcie debaty parlamentarnej oraz poprawki zgłoszone na różnych etapach postępowania legislacyjnego, które przesądziły ostateczny kształt przyjętej regulacji. Zdaniem Autora brak rzetelnej debaty nad istotnymi zmianami prawa wyborczego na etapie poprzedzającym rozpoczęcie prac legislacyjnych zrodził konieczność nowelizacji Kodeksu niemal tuż po jego uchwaleniu. Autor krytykuje również tempo prac nad ustawą, które niekorzystnie wpłynęło na jej ostateczny kształt. Przystąpienie do pierwszego czytania po 10 miesiącach od wniesienia projektu ustawy stanowiło ,istotną i niepotrzebną stratę czasu oraz świadczyło o braku woli po-

Ustawa z dnia 5 stycznia 2011 r. - Kodeks wyborczy (Dz.U. Nr 21, poz. 112 ze zm.).

2 OTKZU nr 6/A/2011, poz. 61. 
litycznej uchwalenia kodeksu" (s. 15). Nagłe przyspieszenie tempa prac ustawodawczych jesienią 2010 r. podyktowane było potrzebą uchwalenia ustawy co najmniej sześć miesięcy przed zbliżającymi się wyborami parlamentarnymi. Pośpiech ten zaowocował niedopracowaniem uchwalonej regulacji oraz przypadkowością przyjmowanych rozwiązań. W rezultacie Autor dochodzi do wniosku, że „znaczenie ustawy, która powinna stać się - ze swej istoty sztandarowym ustrojowym aktem prawnym uchwalonym podczas VI kadencji Sejmu, jeszcze przed wejściem w życie zostało, w następstwie tych wydarzeń, mocno pomniejszone" (s. 35).

Kolejne opracowanie, autorstwa J. Zbieranka, poświęcone jest nowym procedurom wprowadzonym przez Kodeks wyborczy, tj. głosowaniu korespondencyjnemu i przez pełnomocnika. Należy zauważyć, że tematyka ta od lat była przedmiotem zainteresowania Autora ${ }^{3}$, zaś uczestnicząc w pracach Komisji Nadzwyczajnej do rozpatrzenia niektórych projektów ustaw z zakresu prawa wyborczego, miał on pośrednio swój udział w kształcie ostatecznie przyjętej regulacji. Autor przedstawił genezę i starania o wprowadzenie alternatywnych procedur głosowania w Polsce, kształt analogicznych rozwiązań legislacyjnych w innych krajach oraz sposób uregulowania tej materii w Kodeksie wyborczym. W końcowej części opracowania nawiązał do wspomnianego wyżej wyroku Trybunału Konstytucyjnego z 20 lipca 2011 r., sygn. K 9/11 i zawartego w nim rozstrzygnięcia o zgodności z Konstytucją alternatywnych procedur głosowania. Zdaniem Autora: „Wyrok stanowi ważną wskazówkę dla dalszych reform procedur głosowania, podejmowanych również w przyszłości, a dotyczących np. wprowadzenia głosowania przez Internet" (s. 71).

Przedmiotem opracowania J. Szymanka była problematyka komitetów wyborczych. Rozważania Autora nie zostały ograniczone do regulacji prawnej zawartej w Kodeksie wyborczym, lecz objęły również genezę tej instytucji w Polsce oraz jej ewolucję, począwszy od ordynacji wyborczej do Sejmu z 1991 r. Autor zauważa, że początkowo komitet wyborczy był „ekwiwalentem" powstających partii politycznych oraz sposobem nadania jednolitej formuły prawnej różnym podmiotom uczestniczącym w rywalizacji wybor-

\footnotetext{
3 Zob. np. J. Zbieranek, W stronę reformy procedur gtosowania w Polsce [w:] Aktywny obywatel, nowoczesny system wyborczy, pod red. L. Kolarskiej-Bobińskiej, J. Kucharczyka, J. Zbieranka, Warszawa 2006; idem, Głosowanie korespondencyjne [w:] Prawo wyborcze. Analizy, interpretacje, rekomendacje, pod red. J. Zbieranka, Instytut Spraw Publicznych, Warszawa 2009.
} 
czej. Obecnie jest on prawną konstrukcją, która „nie tylko ujednolica zasady gry wyborczej, jednakowo traktując różne przecież podmioty (partie, wyborców, a także organizacje społeczne [...]), ale także jest pewnego rodzaju sposobem gwarantowania powszechności wyborów" (s. 82). W dalszej kolejności Autor analizuje stosowne przepisy Kodeksu wyborczego, w tym dotyczące zasad tworzenia komitetów wyborczych, ich rodzajów, źródeł finansowania oraz przesłanek rozwiązania. Dochodzi do wniosku, że regulacja kodeksowa powtarza w zasadzie wcześniej przyjęte rozwiązania, nie wprowadzając większych, a zwłaszcza istotniejszych, nowości.

Kolejne opracowanie, autorstwa A. Rakowskiej, przedstawia formy i granice kampanii wyborczych według Kodeksu wyborczego. Stawiane tezy Autorka obrazuje przykładami zaczerpniętymi z dotychczasowej praktyki wyborczej. Jako przykład działań naruszających ciszę wyborczą wskazuje eksponowanie przez członków komisji oraz mężów zaufania w dniu głosowania swoim strojem przynależności partyjnej, poruszanie się pojazdami, na których umieszczono plakaty wyborcze czy promowanie kandydatów za pośrednictwem Internetu. Omawiając te przykłady, Autorka przytacza fragmenty stosownych wyjaśnień PKW. Dochodzi do wniosku, że „kodeks w sprawie form, sposobów i granic prowadzenia kampanii wyborczej wprowadził ograniczoną rewolucję. Niestety, rewolucja ta w wielu miejscach jest nieprzemyślana lub nie do końca dopracowana" (s. 135). Autorka przywołuje wyrok Trybunału w sprawie o sygn. K 9/11, przytaczając zawarte w nim rozstrzygnięcie co do niekonstytucyjności zakazu billboardów i płatnych spotów wyborczych. Jednocześnie, kończąc swoje opracowanie, postuluje, by „ustawodawca wycofał się z ograniczeń wielkości plakatów i haseł wyborczych oraz z zakazu rozpowszechniania odpłatnie ogłoszeń wyborczych w mediach" (s. 135), pomijając to, że cel ten już został osiągnięty w następstwie wspomnianego wyżej wyroku Trybunału.

Autorem kolejnego opracowania zatytułowanego Administracja wyborcza w polskim kodeksie wyborczym jest A. Sokala. Przedmiotem jego rozważań stała się problematyka stałych organów wyborczy oraz powoływanych ad hoc komisji wyborczych, a także problematyka wyborczego aparatu pomocniczego. Autor dochodzi do wniosku, że struktura administracji wyborczej zasadniczo nie uległa zmianie. Stawia tezę, że Kodeks wyborczy wzmocnił niezależność służb wyborczych względem innych organów państwowych, zaś wpływ na to miał przyjęty model powoływania i odwoływania członków 
tych służb oraz zapewnienie im odrębności budżetowej. W końcowej części opracowania Autor formułuje postulaty de lege ferenda, wskazując, które przepisy Kodeksu wyborczego i w jakim zakresie wymagałyby - jego zdaniem - poprawienia, ewentualnie uzupełnienia.

Przedmiotem opracowania G. Kryszenia jest problematyka zgłaszania kandydatów w wyborach. Autor zauważa, że Kodeks wyborczy wprowadził pewną uniformizację regulacji prawnej w tym zakresie, przyznając prawo zgłaszania kandydatów we wszystkich wyborach komitetom wyborczym. W opracowaniu w pewnym stopniu zostały powtórzone rozważania dotyczące komitetów wyborczy zawarte we wspomnianym wcześniej opracowaniu J. Szymanka. Poprzedzają one dokonaną przez Autora analizę kodeksowej procedury zgłaszania kandydatów w wyborach. Godne uwagi są przedstawione postulaty de lege ferenda. Pierwszym z nich jest propozycja wprowadzenia kaucji wyborczej wpłacanej przez podmioty zgłaszające kandydatów, która - zdaniem Autora - byłaby „istotnym instrumentem zniechęcania do kandydowania osób niemających szerszego poparcia społecznego" (s. 192). Drugim postulatem jest prawne uregulowanie kluczowych reguł procedury selekcji kandydatów na etapie poprzedzającym ich zgłoszenie. Autor stawia tezę, że tego rodzaju regulacja miałaby charakter gwarancyjny i służyłaby realizacji zasady wolnych wyborów.

Problematyka parytetu w Kodeksie wyborczym została omówiona w opracowaniu, którego autorem jest M. Chmaj. Właściwe rozważania poprzedzają uwagi porównawcze, w ramach których podaje on przykłady krajów, gdzie funkcjonuje system kwot wyborczych, przedstawiając jednocześnie jego wady i zalety. Również w tym opracowaniu znajdziemy nawiązanie do genezę omawianej regulacji ustawowej, w tym do zgłaszanych wcześniej postulatów wprowadzenia parytetu w Polsce. Autor podejmuje próbę oceny zgodność omawianej instytucji z zasadą równości oraz zakazem dyskryminacji. Wyjaśnić jedynie należy, że w tym zakresie konstytucyjności Kodeksu wyborczego nie była przedmiotem kontroli w postępowaniu przed Trybunałem. Autor stawia tezę, że pierwotny projekt ustawy wprowadzający parytety na listy kandydatów, który zawierał zastrzeżenie, że liczba kobiet nie może być mniejsza niż liczba mężczyzn, był niekonstytucyjny, gdyż wprowadzał de facto możliwość dyskryminacji mężczyzn, zaś „w obecnym kształcie ustawy nie ma argumentów przemawiających przeciw zgodności z konstytucją przyjętych rozwiązań” (s. 205). Zdaniem Autora trudno powiedzieć, jaki bę- 
dzie rezultat wprowadzenia kwot wyborczych w Polsce. „Musi upłynąć trochę czasu, zanim ocenić będzie można przydatność wprowadzonej regulacji z perspektywy wzrostu aktywności kobiet w życiu publicznym" (s. 206).

Opracowanie Ł. Buczkowskiego dotyczy stwierdzania ważności wyborów parlamentarnych i prezydenckich na gruncie Kodeksu wyborczego. Autor zwięźle prezentuje regulację konstytucyjną i ustawową, analizując podstawy protestu wyborczego, katalog podmiotów uprawnionych do jego wniesienia, procedurę jego rozpatrzenia oraz skutki stwierdzenia nieważności wyborów. Dochodzi do wniosku, że przyjęty w Kodeksie wyborczym model weryfikacji ważności wyborów „nie jest wolny od budzących wątpliwości rozwiązań, $\mathrm{w}$ większości przyjętych bezkrytycznie z uprzednio obowiązujących ustaw wyborczych" (s. 250).

Kolejne opracowanie, którego autorem jest P. Uziębło, poświęcone jest problematyce finansowania kampanii wyborczej w polskich wyborach parlamentarnych. Zdaniem Autora w odniesieniu do omawianej problematyki Kodeks wyborczy nie wprowadził zasadniczych zmian, zachowując podstawowe założenia ordynacji wyborczej z $2001 \mathrm{r}$. Zwraca jednak uwagę na „nieuzasadnione utrzymanie stosunkowo wysokich limitów wydatków na kampanię wyborczą, przy jednoczesnym ograniczeniu tych metod jej prowadzenia, które były szczególnie kosztochłonne" (s. 267). Pozytywnie ocenia wyraźne rozdzielenie limitów wydatków na potrzeby kampanii do Sejmu i do Senatu. Pewne wątpliwości, zdaniem Autora, budzą niewielkie zmiany w zakresie sprawozdawczości finansowej. Odwołując się do wzorów brytyjskich i chilijskich, wskazuje on na możliwość przyznania PKW prawa do bezpośredniej ingerencji $\mathrm{w}$ sferę wykazanych $\mathrm{w}$ sprawozdaniu wydatków. Zwraca uwagę na zalety sankcji za przekroczenie limitu wydatków w postaci utraty mandatu parlamentarnego.

Ostatnie opracowanie, którego autorem jest K. Składowski, dotyczy oceny regulacji wyborów do Senatu z punktu widzenia zasady równości wyborów. Na podstawie dokonanych obliczeń dochodzi on do wniosku, że po wejściu w życie Kodeksu wyborczego blisko połowa okręgów wyborczych odbiega od normy przedstawicielskiej o ponad 15\%, zaś w czterech okręgach różnica ta wynosi ponad 50\%. Dysproporcje te Autor przedstawił za pomocą stosownych tabel. Stawia tezę, że „mimo iż przepisy kodeksu posługują się pojęciem normy przedstawicielstwa, to szczegółowe zasady wyznaczania granic okręgów wyborczych powodują, że nie sposób wyznaczyć struktury jednoman- 
datowych okręgów wyborczych, która realizowałaby postulat równości materialnej wyborów. Wynika to z zamiaru pogodzenia w kodeksie struktury okręgów wyborczych do Senatu z granicami okręgów wyborczych w wyborach do Sejmu oraz podziałem państwa na województwa" (s. 291-292).

Podsumowując, należy stwierdzić, że recenzowana publikacja stanowi cenną i godną uwagi pozycję wydawniczą. Jej podstawowymi zaletami są niebywała aktualność, bogactwo i różnorodność poruszanych problemów oraz rzetelność analizy nowych regulacji prawnych. Weryfikacja sformułowanych w niej tez i konkluzji, jak zauważa redaktor tomu we Wstępie, „W dużej mierze będzie następować pod wpływem doświadczeń wynikających z kolejnych wyborów” (s. 9).

Monika Florczak-Wątor (Uniwersytet Jagielloński w Krakowie) 